\title{
Mikroplastika u morskom okolišu Jadrana
}

\author{
K. Bule, ${ }^{a}$ K. Zadro, ${ }^{a}$ A. Tolić, ${ }^{a}$ E. Radin, ${ }^{a}$ M. Miloloža, ${ }^{a}$ \\ V. Ocelić Bulatovićb i D. Kučić Grgića* \\ a Sveučilište u Zagrebu, Fakultet kemijskog inženjerstva i tehnologije \\ Marulićev trg 19, 10000 Zagreb \\ b Sveučilište u Zagrebu, Metalurški fakultet, Aleja narodnih heroja 3, 44000 Sisak
}

Ovo djelo je dano na korištenje pod Creative Commons Attribution 4.0 International License

\begin{abstract}
Sažetak
\section{Ključne riječi}

Mikroplastika, onečišćenje plastikom, morski okoliš, toksičnost, Jadransko more
\end{abstract}

Plastika se zbog svoje široke uporabe može naći u svim dijelovima okoliša, gdje štetno utječe na različite sastavnice okoliša, a toksični spojevi koje adsorbira prenose se kroz hranidbene lance te s vremenom dolaze do čovjeka. Odabrana istraživanja u ovom radu usredotočena su na karakterizaciju i kvantifikaciju mikroplastike pronađene u Jadranskom moru kao i na toksičnost mikroplastike. Istraživanja su pokazala da je najviše mikroplastike detektirano u području Sjevernog Jadrana. Provedena ispitivanja ekotoksičnosti mikroplastike primjenom testa s algama ukazuju na to da mikroplastika uzrokuje smanjenje brzine rasta i kretanja algi, obavljanje fotosinteze, fizičke deformacije te dolazi do smanjenja plodnosti i promjena u metaboličkim ciklusima.

\section{Uvod}

Problem plastike i mikroplastike koja svakim danom završava u okolišu postoji od davnina. Porastom ljudske populacije raste i proizvodnja plastike, što nam govori podatak da se globalna proizvodnja plastike povećala s 1,5 milijuna tona u 1950-ima na 359 milijuna tona u 2018. godini. ${ }^{1}$ Zahvaljujući dugotrajnosti i visokoj ekonomičnosti, plastika ima ključnu ulogu u mnogim gospodarskim sektorima, kao što su pakiranje, graditeljstvo, transport, proizvodnja električne energije i elektroničkih uređaja, poljoprivreda, medicinske ustanove i sport. ${ }^{2}$ Većina proizvedene plastike upotrebljava se kao ambalaža koja može postati otpad nakon kratkog vijeka trajanja. ${ }^{2}$ Zbog velike upotrebe plastičnih proizvoda, ljudskog nemara i nepropisnog odlaganja, većinski dio proizvedene plastike završava u morima, oceanima, jezerima, tlu i svim ostalim sastavnicama okoliša, gdje štetno utječe na okoliš i žive organizme. ${ }^{2}$ Onečišćenje plastikom postalo je problem na globalnoj razini. Zakonodavstvo i gospodarenje otpadom u početku se odnosilo na makroplastiku jer je ona okom vidljiva i bila je prioritet. Različiti zakoni zabranjuju nepropisno odlaganje plastike u okoliš, ali u novije vrijeme sve se više pažnje pridaje upravo mikroplastici. ${ }^{1-3}$ Međutim, još uvijek ne postoje konkretni zakoni koji propisuju dopuštene količine mikroplastike u okolišu. Ljudi još nisu svjesni da odlaganjem plastike u okoliš zapravo na kraju narušavaju svoje zdravlje. Većina otpada koji se pronađe u prirodi, pa tako i plastika, ulazi u neprestani kružni tok. Nakon što završi u prirodi, plastika podliježe različitim procesima degradacije te dolazi do njezinog usitnjavanja, čime nastaje mikroplastika koju organizmi poput riba unose u prehrambeni lanac i koja u konačnici završava u tijelu čovjeka. Mikroplastika

*Autor za dopisivanje: doc. dr. sc. Dajana Kučić Grgić e-pošta: dkucic@fkit.hr

Rad je prezentiran na VII. hrvatskom simpoziju o kemiji i tehnologiji makromolekula 2019. je vrlo štetan oblik plastike i zbog svojih toksičnih svojstava narušava zdravlje svih živih organizama. ${ }^{3,4} \mathrm{Uz}$ to je vrlo dobar adsorbens ${ }^{4}$ i na sebe veže većinu štetnih tvari koje se nađu u njezinoj blizini, što je čini još štetnijom za žive organizme. Najveće količine mikroplastike mogu se pronaći u morima i oceanima. Istraživanja pokazuju da se svake godine oko 8 milijuna tona mikroplastike ispušta u oceane. ${ }^{4}$ Pretpostavlja se da će se do 2050 . godine u morima i oceanima nalaziti više plastike nego ribe. ${ }^{2} U$ ovome radu poseban naglasak stavljen je na mikroplastiku u Jadranskom moru, odnosno na dosadašnja istraživanja vezana uz prisustvo mikroplastike u sjevernom, srednjem i južnom Jadranu. Također, kroz rad je dan literaturni pregled vezan uz toksičnost mikroplastike kao i utjecaj na ekosustav.

\section{Teorijski dio}

\subsection{Mikroplastika}

Plastika je stabilan polimerni materijal koji se sastoji od velikog broja polimera, ${ }^{2}$ uključujući polipropilen (PP), polietilen (PE), polistiren (PS), poli(vinil-klorid) (PVC), poli(etilen-tereftalat) (PET) te poliamid (PA) koji su uglavnom dobiveni iz fosilnih goriva poput nafte, prirodnog plina i ugljena, u petrokemijskoj industriji. Plastika je teško razgradljiva, ali pod utjecajem okolišnih čimbenika poput vjetra, sunca i valova dolazi do njezine degradacije na sitnije čestice i akumuliranja u okolišu. ${ }^{3}$ Mikroplastika se općenito definira kao plastika manja od $5 \mathrm{~mm}$ koja, kada se nađe u okolišu, predstavlja neprimjetan, ali opasan oblik onečišćenja zbog svojih štetnih svojstava. ${ }^{4}$ Postoje dva izvora mikroplastike, a to su: primarni i sekundarni izvori. ${ }^{4}$ Pod primarne izvore podrazumijevamo namjerno proizvedene čestice mikroplastike, na primjer, kuglice mikroplastike i mikroplastiku koja se upotrebljava u industriji (vlakna i prašci), deterdžentima, kozmetičkim proizvodima, proi- 
zvodima za higijenu, odjeći itd. ${ }^{3,4}$ Primarna mikroplastika najčešće dospijeva u okoliš ispuštanjem nedovoljno obrađenih otpadnih voda iz različitih industrijskih postrojenja i postrojenja za obradu komunalnih otpadnih voda. ${ }^{5}$ Pod sekundarne izvore spada mikroplastika nastala degradacijom makroplastike. ${ }^{4}$ Sekundarna mikroplastika zauzima najveći udio kad se govori o mikroplastici koja onečišćuje oceane, mora, obalne sredine, sediment, pa čak i arktičko područje. ${ }^{3,4}$

\subsection{Svojstva mikroplastike}

Mikroplastika sama po sebi nije toksična, međutim, ako je organizam dugotrajno izložen mikroplastici, može doći do trovanja organizma zbog prisutnosti aditiva u njoj poput plastifikatora (ftalati), pigmenta, stabilizatora i antioksidansa (bisfenol A, spojevi kadmija i olova), sredstva protiv klizanja (amidi masnih kiselina), biocida (spojevi arsena) i dr. ${ }^{5}$ Također može doći do različitih upala prilikom gutanja zbog oštrih rubova mikroplastike. ${ }^{5}$ Mikroplastika se može fizikalno i kemijski okarakterizirati. Fizička karakterizacija odnosi se uglavnom na raspodjelu veličine mikroplastike kao i na procjenu drugih fizikalnih parametara kao što su oblik i boja. ${ }^{5} \mathrm{~S}$ druge strane, kemijska se karakterizacija uglavnom primjenjuje pri istraživanju sastava mikroplastike te se u tu svrhu upotrebljavaju različiti uređaji poput Fourier-transform infrared spektrofotometra (FTIR), Raman spektrofotometra, skenirajućeg elektronskog mikroskopa (SEM) te uređaja za tekućinsku kromatografiju visoke djelotvornosti (HPLC) i za plinsku kromatografiju/masenu spektrometriju (GC/MS). ${ }^{5}$ Makroplastika i mikroplastika u morskim i obalnim sredinama podvrgnuta je toplinskom zračenju i oksidaciji, što rezultira degradacijom polimera odnosno mijenjaju se fizikalna i kemijska svojstva poput boje, morfološke površine, kristalne strukture, veličine čestica i gustoće. ${ }^{4,6}$ Mikroplastika uglavnom ima manju gustoću od vode i nije biološki razgradljiva, ali u vodenoj sredini mikroorganizmi je koloniziraju i stvaraju biofilm. Nastali biofilm ima važnu ulogu u raspodjeli mikroplastike u vodi jer povećava njezinu gustoću i zbog težine ona tone na dno vode, gdje se istaloži na sediment. ${ }^{4}$ Čestice mikroplastike, iako imaju mali promjer, imaju veliku aktivnu površinu i na sebe vežu brojne onečišćujuće tvari, što pridonosi njezinoj toksičnosti. Na površinu mikroplastike adsorbiraju se teški metali, patogene i organske onečišćujuće tvari poput polikloriranih bifenila (PBC), policikličkih aromatskih ugljikovodika $(\mathrm{PAH})$ te heksaklorcikloheksana $(\mathrm{HCH})$ i diklordifeniltrikloretana (DDT) odnosno pesticida. 2,3,7 Adsorpcija onečišćujućih tvari na mikroplastiku ovisi o više čimbenika: starosti mikroplastike, ${ }^{3,6}$ blizini onečišćujućih tvari, ${ }^{3}$ vrsti mikroplastike i njezinoj molekulskoj strukturi, ${ }^{6}$ polarnosti mikroplastike, ${ }^{3,4,6}$ omjeru površine i volumena mikroplastike ${ }^{6}$ te o uvjetima u okolišu. ${ }^{3,6}$ Upravo zbog navedenih svojstava ona predstavlja veliku opasnost za okoliš i žive organizme.

\subsection{Ispitivanje štetnih učinaka mikroplastike}

Ekotoksikološka ispitivanja provode se zbog utvrđivanja štetnih utjecaja koje ispitivana tvar ima na organizam, populaciju, ekosustav i biosferu. ${ }^{8}$ Provode se na organizmima koji su jednostavni za održavanje u laboratoriju te imaju jednostavniji razvojni mehanizam koji se može primijeniti na složenije mikroorganizme. Najčešće korišteni organizmi/mikroorganizmi na kojima se provode eksperimenti su nematoda Caenorhabditis elegans, vinska mušica Drosophila melanogaster, žaba Xenopus laevis, miš Mus musculus, zebrafish Danio rerio, vodenbuha Daphnia magna, morski račići, morska bakterija Vibrio fischeri, bakterija Pseudomonas putida i slatkovodne i morske mikroalge (Microcystis panniformis, Scenedesmus sp. i Skeletonema costatum) zbog jednostavnosti, relativno su mali, imaju jednostavnu anatomiju i kratak životni vijek. ${ }^{8}$ Mikroplastika se iz okoline akumulira i prolazi kroz žive organizme. Pri tome izaziva različite biološke učinke u organizmima, kao što su poremećaji u metabolizmu, oksidativni stres, imunološka, neurološka i histološka oštećenja te oštećenja DNA. ${ }^{9}$ Ovisno o veličini, koncentraciji i vrsti te interakciji mikroplastike s drugim štetnim tvarima, mikroplastika različito utječe na živa bića i okoliš. ${ }^{9}$

\subsubsection{Ispitivanje štetnih učinaka mikroplastike primjenom mikroalgi}

Sve veće količine mikroplastike u vodenim sustavima utječu na razvoj različitih populacija, uključujući i alge, smanjujući dostupnost ili apsorpciju hranjivih tvari. Mikroalge su autotrofni fotosintetski organizmi i jedne su od najvažnijih primarnih proizvođača u vodenim i morskim ekosustavima. ${ }^{10,11}$ Nadalje, nalaze se na dnu hranidbene piramide, odnosno čine bazu hranidbenog lanca te o njima ovisi postanak gotovo svih vrsta. Morske alge u podnožju morskog lanca hrane služe kao vrlo dobar bioindikator ${ }^{10}$ onečišćujućih tvari u moru. S toksikološkog gledišta, mikroalge imaju mnoge prednosti kao biološki model za procjenu toksičnosti mikroplastike poput njihova kratkog razdoblja rasta, jednostavnosti rada i promatranja te visoke osjetljivosti na različite tipove onečišćujućih tvari u vodenim sredinama. ${ }^{12}$ Istraživanja su pokazala negativan utjecaj mikroplastike na većinu ispitanih mikroalgi. Pri ingestiji mikroplastike, mikroplastika neizravno utječe na sve razine prehrambenog lanca. Mikroplastika utječe na pokazatelje kao što su rast, sadržaj klorofila, aktivnost fotosinteze, morfologiju (zadebljanje stanične stijenke) i povećava proizvodnju reaktivne vrste kisika (ROS) koja je toksična. ${ }^{10}$ Istraživanja su pokazala kako mikroplastika inhibira rast mikroalgi Microcystis panniformis, ${ }^{13}$ Scenedesmus sp. ${ }^{13}$ i Skeletonema costatum. ${ }^{14}$ Istraživanje temeljeno na izloženosti mikroalge Skeletonema costatum mikroplastici rezultiralo je i njezinim fizičkim oštećenjem te oksidativnim stresom. ${ }^{14}$ Do velikog povećanja toksičnosti mikroplastike dovode onečišćujuće tvari adsorbirane na njezinu površinu. Na primjer, dokazano je kako mikroplastika ne utječe značajno na rast mikroalge Isochrysis galbana, ${ }^{12}$ ali kada je na nju adsorbiran pesticid klorpirifos, tada dolazi do promjene morfologije navedene mikroalge, inhibicije njezina rasta i oštećenja DNK. ${ }^{12}$ Nadalje, istraživanja ukazuju na to da mikroplastika negativno utječe na proces fotosinteze, ali to područje još nije dovoljno dobro istraženo, te se ne može sa sigurnošću reći na koji način dolazi do negativnog učinka. Većina stručnjaka tvrdi da do negativnog utjecaja dolazi zbog adsorpcije mikroplastike na mikroalge koja algama onemogućava dostupnost sunčeve svjetlosti nužne 
za odvijanje procesa fotosinteze, ${ }^{11}$ dok drugi tvrde da mikroplastika smanjuje koncentraciju klorofila, ${ }^{15}$ koji je također nužan za proces fotosinteze. Jedno istraživanje je upravo to i dokazalo ispitujući utjecaj PP i PVC na slatkovodne alge Chlorella pyrenoidosa i Microcystis flos-aquae. ${ }^{15}$ Kada je koncentracija PVC-a bila iznad $250 \mathrm{mgl}^{-1}$, u usporedbi s kontrolnom skupinom u kojoj alge nisu bile izložene mikroplastici, sadržaj klorofila mikroalge Chlorella pyrenoidosa smanjen je za čak 55,23 \%. ${ }^{15}$ Tom studijom dokazano je da je PVC toksičniji od PP-a te da mikroplastika može uvelike utjecati na proces fotosinteze, pogotovo pri većim koncentracijama. ${ }^{15}$

\subsubsection{Ispitivanje štetnih učinaka mikroplastike primjenom drugih organizama i mikroorganizama}

Brojna istraživanja zabilježila su gutanje i akumuliranje različitih oblika mikroplastike unutar različitih vrsta beskralježnjaka, ali bez štetnih učinaka na te organizme. ${ }^{11-14}$ Podatci tih istraživanja dani su u tablici 1. S druge strane, neka istraživanja pokazala su štetne učinke na neke organizme (tablica 2). Osim navedenih negativnih učinaka mikroplastike na vodene organizme u tablici 2, velik problem stvara i translokacija čestica mikroplastike u druga tkiva, što dovodi do smanjenja rasta i/ili plodnosti određenih organizama. Istraživanja su pokazala kako se polistirenska mikroplastika može premjestiti iz crijeva dagnje ${ }^{11}$ (M. edulis) u krvožilni sustav, što dovodi do različitih upala i pada njezina imuniteta. Uočeno je i nakupljanje PS mikroplastike u škrgama, jetri i crijevima zebrice ${ }^{11}$ (Danio rerio), što rezultira upalom, akumulacijom lipida u jetri i povišenjem enzimskih biomarkera oksidativnog stresa. ${ }^{11}$

\subsection{Utjecaj mikroplastike na ekosustav}

Mikroplastika je danas raširena u svim ekosustavima, a posebno je zabrinjavajuć njezin utjecaj na morske ekosustave gdje ona predstavlja prijetnju bioraznolikosti sustava. ${ }^{16}$ Ribe često plastiku zamijene za hranu. UN-ove procjene
Tablica 1 - Oblici unesene mikroplastike gutanjem pronađeni u različitim vodenim organizmima (beskralježnjacima) bez zabilježenih štetnih učinaka ${ }^{11}$

Table 1 - Forms of ingested microplastic found in various aquatic organisms (invertebrates) with no adverse effects ${ }^{11}$

\begin{tabular}{l|l}
\hline Vodeni organizam (beskralježnjak) & $\begin{array}{l}\text { Oblik unesene } \\
\text { mikroplastike }\end{array}$ \\
\hline smeđi škampi (Cragnon cragnon (L.)) & vlakna i čestice \\
\hline $\begin{array}{l}\text { ličinke pacifičke ostrige } \\
\text { (Crassostrea gigas) }\end{array}$ & mikročestice \\
\hline $\begin{array}{l}\text { ličinke morskog ježa } \\
\text { (Tripneustes gratilla) }\end{array}$ & mikrosfere \\
\hline morski rak (Idotea emarginata) & mikročestice \\
\hline školjke (Lepas spp.) & vlakna i mikročestice \\
\hline morski krastavci (Echinodermata) & vlakna i mikročestice \\
\hline morski puž (Littorina littorea) & kuglice \\
\hline ličinke morskog račića (Artemia sp.) & mikročestice \\
\hline blatni puž (Potamopyrgus antipodarum) & mikročestice \\
\hline
\end{tabular}

govore da otprilike 30 \% riba u svojem tkivu sadrži mikroplastiku, ${ }^{17}$ a ona je pronađena i u kamenicama, dagnjama i tunama. ${ }^{8}$ Prema izvješću UNEP-a iz 2012. godine, mikroplastika u morima i oceanima nepovoljno je utjecala na sposobnost reprodukcije morskih organizama, sposobnost hvatanja plijena, lomljivost kostiju, tjelesnu spremnost o kojoj ovisi njihovo preživljavanje te potraga za hranom traje znatno dulje. ${ }^{17}$ Dodatno, mikroplastika može zatvoriti probavni sustav životinja koje ju zamijene za plijen, odnosno hranu, i na taj način uzrokovati njihovo uginuće. Različite mikrobne zajednice rabe mikroplastiku kao pribježište ili kao prijenosnika potencijalno patogenih mikrobnih vrsta. ${ }^{18}$ Mikroplastika niže gustoće $\left(0,910-0,940 \mathrm{~g} \mathrm{~cm}^{-3}\right)$ akumulirana je u oceanskim vrtlozima, zbog čega ugrožava beskralježnjake koji se u njima nalaze. ${ }^{17}$ Mikroplastika veće gustoće $\left(\geq 0,941 \mathrm{~g} \mathrm{~cm}^{-3}\right)$ taloži se iz slobodnog stupca

Tablica 2 - Zabilježeni štetni učinci mikroplastike uočeni na beskralježnjacima ${ }^{11}$

Table 2 - Adverse effects of microplastics observed on invertebrates ${ }^{11}$

\begin{tabular}{l|l}
\hline Vodeni organizam (beskralježnjak) & Negativni učinci mikroplastike \\
\hline veslonošci (kopepodni račići) & Otežano kretanje (plivanje) \\
\hline rotifere (Brachionus koreanus) & $\begin{array}{l}\text { smanjena stopa rasta, smanjena plodnost, smanjen životni vijek, dulje vrijeme } \\
\text { reprodukcije i povišenje razine enzimskih biomarkera stresa }\end{array}$ \\
\hline veslonošci (Calanus helgolandicus) & smanjena sposobnost hranjenja i smanjen reproduktivni učinak \\
\hline veslonošci (Tigriopus japonicus) & smanjena plodnost \\
\hline azijske zelene dagnje (Perna viridis) & $\begin{array}{l}\text { otežano preživljavanje - negativan učinak na filtraciju i respiraciju, kao i na proizvodnju } \\
\text { snopa vlakana koje dagnjama služe za pričvršćivanje na čvrstu podlogu }\end{array}$ \\
\hline rakušci (Gammarus fossarum) & smanjena stopa rasta \\
\hline glavoč (Pomatoschistus microps) & smanjena sposobnost bijega od predatora \\
\hline poliketni crv (Marina Arenicola) & $\begin{array}{l}\text { znatno smanjenje zaliha energije zbog smanjene aktivnosti hranjenja, nakupljanja } \\
\text { mikroplastike u crijevima i s tim povezane upale }\end{array}$ \\
\hline bočati rak (Carcinus maenas) & smanjena potrošnja hrane i smanjena raspoloživa energija za rast \\
\hline
\end{tabular}


vode, a najviše utječe na bentonsku zajednicu. ${ }^{17}$ Dekapodni rakovi hrane se bentonskom faunom i na taj način u organizam unose mikroplastiku. Osim hranjenjem, rakovi čestice mikroplastike unose i pasivno, iz sedimenta u kojem su one istaložene. Smatra se da su organizmi koji nastanjuju morski sediment pojačano izloženi utjecaju mikroplastike koja na sebe može vezati do sto puta veće koncentracije onečišćujućih spojeva nego sediment. ${ }^{19}$ Istraživanje provedeno na pjeskuljama (Arenicola marina), morskim mnogočetinašima koji razgrađuju morski sediment, pokazalo je štetan utjecaj mikroplastike. Pjeskulje su bile izložene sedimentu koji je sadržavao 5 \% mikroplastike na koju su bili adsorbirani fenentren, triklosan te nonilfenol, tj. spojevi koji se nalaze u kozmetičkim proizvodima. Mikroplastika i adsorbirani spojevi uzrokovali su povećanu smrtnost pjeskulja, jer se smanjila učinkovitost prerade sedimenta (za $55 \%$ i nonilfenol je za $60 \%$ umanjio sposobnost uklanjanja patogenih mikroorganizama. ${ }^{19}$ Upravo je sposobnost mikroplastike da na sebe veže toksične spojeve, koji putem hranidbenih lanaca naposljetku dolaze do čovjeka, njezino najopasnije svojstvo, slika $1 .{ }^{19,20} \mathrm{U}$ toksične spojeve koji se adsorbiraju na površinu mikroplastike pripadaju i ftalati koji ometaju rad endokrinog sustava te imaju štetno djelovanje na jetru. ${ }^{21}$ Oni se kao "omekšivači" upotrebljavaju u kozmetici, ambalaži, pastama za zube, bojama, gelovima za tuširanje i parfemima. Zbog njihove široke primjene vrlo su česta sastavnica morskog otpada te je utvrđeno da se u visokim koncentracijama nalaze i u tijelu velikih morskih sisavaca, primjerice dupina, kitova i ulješura, a pronađeni su i u meduzi iz Atlantskog oceana koja je obitavala na $1000 \mathrm{~m}$ dubine. ${ }^{22}$ Istraživanje WWF-a (engl. World Wide Fund for Nature - svjetske organizacije za zaštitu prirode) također je potvrdilo tu činjenicu. Provedenom biopsijom na 100 morskih sisavaca utvrđena je visoka koncentracija ftalata u kitovima. ${ }^{23}$ Školjkaši su skupina morskih organizama koji su zbog svojeg načina prehrane pojačano izloženi mikroplastici, te su zbog toga dobar pokazatelj opterećenosti vode mikroplastikom. ${ }^{17}$ Školjkaši u jednom satu profiltriraju otprilike 2 I morske vode. Procjenjuje se da čovjek godišnje u organizam unese 11000 čestica mikroplastike konzumirajući školjkaše. ${ }^{17}$

\subsection{Mikroplastika u moru}

Posljednjih godina onečišćenje morskog okoliša mikroplastikom privlači sve veću pozornost. Plastika i mikroplastika glavne su komponente morskog otpada - one zauzimaju oko 60 - $80 \%$, u nekim područjima čak do $95 \% .{ }^{24}$ Voda koja se svakodnevno upotrebljava, kako u kućanstvu tako i u industrijskim postrojenjima, nakon upotrebe, kanalizacijskim sustavom odvodi se na pročišćavanje i vraća u prirodni okoliš. Male dimenzije mikroplastike omogućuju lagani prolaz kroz filtre pri pročišćavanju otpadnih voda te ona završava u rijekama, a kasnije i u morima. Gotovo da je nemoguće ukloniti mikroplastiku iz vodenih sustava, a da se ne poremeti funkcioniranje ekosustava jer se postupcima poput vađenja mikroplastike pomoću mreža istodobno uklanja plankton i ostali mikroorganizmi. ${ }^{17,25}$ Mnogobrojna istraživanja temeljena su na mikroplastici u površinskom sloju mora, no istraživanjima iz 2006. na području Kine i Koreje ukazano je i na mogućnost prisutnosti mikroplastike u dubljim dijelovima mora. ${ }^{24}$ Također, djelovanjem valova i morskih struja, plutajuća mikroplastika iz morskih stupaca može dospjeti do morskih plaža, gdje se nakuplja. Prema procjeni WWF-a, svjetskim morima pluta 5000 milijardi čestica manjih od pet milimetara. ${ }^{17}$ Gustoća mikroplastike slična je gustoći morske vode, a nerijetko su čestice i znatno lakše od morske vode, te će stoga u pravilu plutati ili se zadržati u stupcu. Međutim, kako gustoća morske vode raste s povećanjem dubine, dubina će utjecati na raspored samih čestica u stupcu vode. ${ }^{26}$ Količina biofilmova, bakterija i epifita mijenja se ovisno o sezoni i povećana je tijekom ljetnih mjeseci. ${ }^{27,28}$

\subsection{Mikroplastika u Jadranskom moru}

Bez obzira na izvor, otpad u Jadranskom moru trajan je ekološki i sociološki problem svake države koja mu gravitira. Prema količini i zastupljenosti plastičnog otpada, Jadransko more je najonečišćenije u Europi nakon sjeveroistočnog dijela Sredozemnog i Keltskog mora. ${ }^{29}$ Otpad u Jadransko more dospijeva od oko četiri milijuna ljudi koji

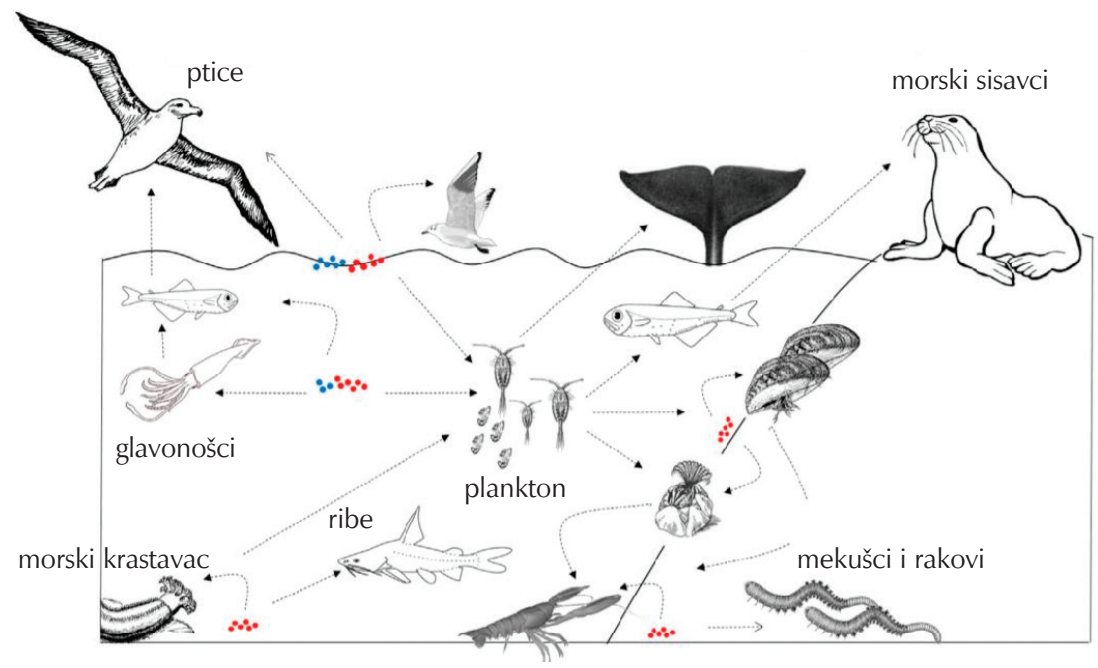

Slika 1 - Unos mikroplastike i toksičnih spojeva putem hranidbenog lanca ${ }^{20}$

Fig. 1 - Intake of microplastics and toxic compounds through the food chain ${ }^{20}$ 
žive uz njegove obale, ali se taj broj tijekom turističke sezone poveća gotovo šest puta. ${ }^{29}$ Također, nastali otpad je i posljedica industrija u priobalju, kao i intenzivnog brodskog prometa te režima morskog strujanja. Na plažama i morskom dnu priobalnog područja Hrvatske otpad iz mora prisutan je u količinama koje nisu zanemarive. Na hrvatsku su obalu velike količine otpada donesene morskim strujama i vjetrom iz susjednih jadranskih zemalja (Albanije, Italije), naročito za vrijeme iznimno nepovoljnih meteoroloških i hidroloških prilika. ${ }^{29}$ Takav otpad na području južnog Jadrana čini gotovo 90 \% udjela u ukupnoj količini. ${ }^{30-32} \mathrm{Na}$ slici 2 prikazana su mjesta uzorkovanja mikroplastike na području Jadranskog mora. ${ }^{33}$

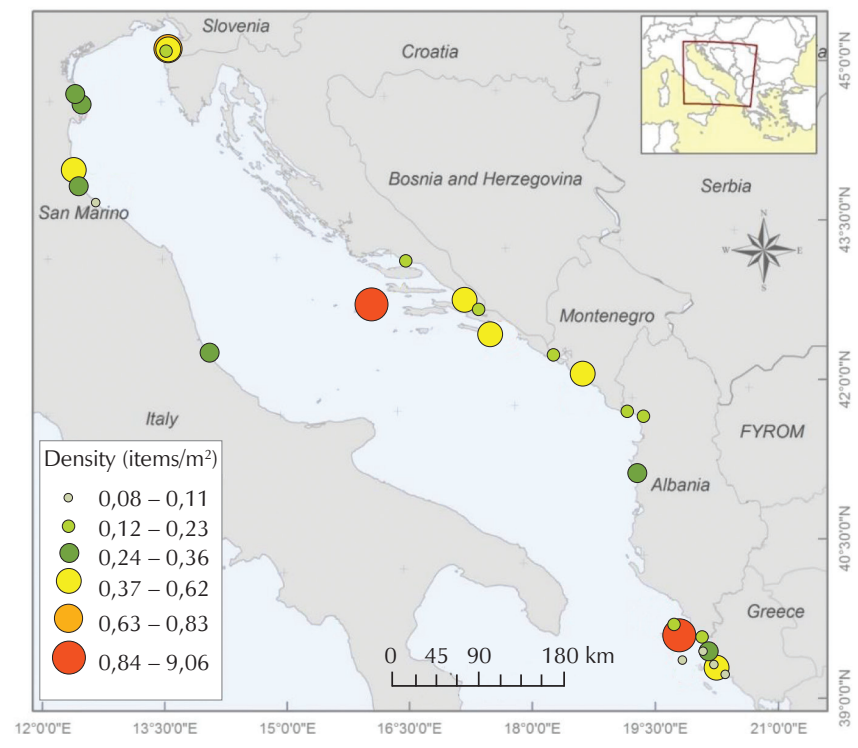

Slika 2 - Mjesta uzorkovanja mikroplastike u Jadranskom moru ${ }^{33}$ Fig. 2 - Sampling sites of microplastics in the Adriatic Sea ${ }^{33}$

\subsubsection{Sjeverni Jadran}

Godine 2016. provedeno je istraživanje stupnja onečišćenja mora mikroplastikom u području sjevernog Jadrana (Tršćanski zaljev). U moru su detektirane izrazito visoke koncentracije mikroplastike, prosječne vrijednosti od oko 406000 čestica $/ \mathrm{km}^{2}$, što je do sad među najvišim zabilježenim koncentracijama u Mediteranskom moru. ${ }^{34}$ Nadalje, istraživanjem na $10 \%$ uzoraka mikroplastike, utvrđeno je da 80 \% čestica čini polietilen, a 14 \% čestica nije identificirano. Ostatak zauzimaju polipropilen, polistiren, poli(vinil-klorid) te akrilo/butadien/stiren (ABS). Sve identificirane čestice mikroplastike dimenzijom su manje od 0,3 mm. Razlog dominacije PE-a i PP-a jest njihova mala gustoća, tj. manje su gustoće od gustoće vode uslijed čega te čestice plutaju na površini mora. ${ }^{34}$ Studija koja datira iz 2014. godine daje na uvid stanje sedimenata sa šest plaža (plićak i obalni sediment) na području Tršćanskog zaljeva. Dokazano je da sedimenti u najvećoj količini sadrže mikroplastiku veću od $1 \mathrm{~mm}$ i to u obliku vlakana $(75-96 \%),{ }^{35}$ dok je druga najzastupljenija skupina fragmentirana mikroplastika (21\%). ${ }^{35}$ Sva pronađena mikroplastika je nastala fragmentiranjem makroplastike ili u moru ili na kopnu različitim procesima. Mogući izvori mikroplastike su i rijeke koje se ulijevaju u Tršćanski zaljev koje sadrže mikroplastiku koja je prošla kroz filtre za pročišćavanje otpadnih voda zbog malih dimenzija. ${ }^{35-38}$

\subsubsection{Središnji Jadran}

Institut za oceanografiju i ribarstvo iz Splita bavi se problematikom otpada iz mora u okviru projekta "Sustav gospodarenja napuštenom ribolovnom opremom u Jadranskoj regiji" (engl. Derelict Fishing Gear Management System in the Adriatic Region; skraćenica DeFishGear). ${ }^{29}$ Projektne aktivnosti provodi tim u koji su uključeni istraživački instituti, nacionalne i lokalne vlasti i nevladine udruge iz svih zemalja Jadransko-Jonske regije. Projekt je osmišljen s ciljem jačanja suradnje i poticanja zajedničkih i usklađenih akcija za čišćenje Jadrana. To je prvi projekt vezan za istraživanje mikroplastike u Jadranskome moru. U sklopu projekta uzorkovan je morski otpad s plaža, površine mora, morskog dna, mikroplastika u ribama, izgubljene ribarske mreže te otpad iz ribarskih luka Vira i Tribunj. ${ }^{29}$ Projekt je osmišljen kako bi se pristupilo regionalnom razvoju praćenja i procjene prisutnosti mikroplastike i njezine raspodjele u morskom okolišu, kao i utvrđivanje mogućih izvora. Količina i sastav mikroplastike istraživala se na području srednjeg Jadrana te na ušću rijeke Neretve, koji predstavljaju područja potencijalne akumulacije te vrste otpada. Rezultati ukazuju da je veća količina mikroplastike zabilježena u uzorcima bliže obali zbog blizine potencijalnih izvora otpada s kopna. Također, praćena je i količina mikroplastike s obzirom na godišnja doba. Uzorci pijeska i sedimenta s pješčanih plaža uzorkovani su tijekom i nakon turističke sezone (plaža Bačvice (Split), plaža Zaglav (Vis) te plaža u neposrednoj blizini ušća rijeke Neretve). Na plažama Bačvice i Zaglav detektirana je veća količina mikroplastike ljeti, odnosno tijekom turističke sezone (tablica 3), dok je na ušću rijeke Neretve količina fragmenata mikroplastike bila daleko veća nego na plažama Bačvice i Zaglav. ${ }^{29}$

Godine 2014. provedeno je istraživanje pojave, količine i tipa mikroplastičnog otpada u gastrointestinalnom traktu ribe List (Solea solea) te prostorna raspodjela mikroplastike u sjevernom i središnjem Jadranskom moru na dubinama 20 - 120 m. U 95 \% uzorkovanih riba pronađene su čestice mikroplastike, a $80 \%$ ispitivanih riba sadržavalo je više od jedne vrste mikroplastike. ${ }^{39}$ Istraživanje provedeno u zadarskom arhipelagu, vrlo razvedenom području s mnogo usporednih otoka i kanala, pokazalo je da se veće koncentracije mikroplastike na morskom dnu zadržavaju u priobalnim područjima. Prosječna koncentracija mikroplastike u moru je 127000 čestica $/ \mathrm{km}^{2}$, a na morskom dnu 36 čestica/100 g suhog sedimenta. ${ }^{40}$ Godine 2016. provedeno je istraživanje mikroplastike na području središnjeg Jadrana u kojem su se odredile koncentracije metala adsorbiranih na površini mikroplastike. Uzorci sedimenta uzeti su u proljeće i jesen s dviju pješčanih plaža, Zaglav i Milna. $U$ uzorcima sedimenta bili su prisutni različiti metali; $\mathrm{Cd}, \mathrm{Cr}$, Cu, Fe, Mn, Ni, Pb i Zn u različitim koncentracijama. Sezonske razlike u koncentraciji metala povezane su s različitim karakteristikama vjetra u pojedinom razdoblju godine. Najveće koncentracije metala detektirane su u proljeće. Postoje dva moguća izvora metala izmjerena u 
Tablica 3 - Sastav mikroplastike na plažama Bačvice, Zaglav i ušće Neretve prije i nakon turističke sezone ${ }^{29}$ Table 3 - Microplastics composition at Bacvice and Zaglav beaches and Neretva estuaries before and after the tourist season ${ }^{29}$

\begin{tabular}{|l|c|c|c|c|c|c}
\hline & \multicolumn{2}{|c|}{ Bačvice } & \multicolumn{2}{c|}{ Zaglav } & \multicolumn{2}{c}{ Neretva } \\
\hline Sastav mikroplastike / \% & ljeto 2014. & jesen 2014. & ljeto 2014. & jesen 2014. & ljeto 2014. & jesen 2014. \\
\hline fragmenti & 67 & 55 & 41 & 35 & - & 91 \\
\hline filamenti & 29 & 35 & 28 & 2 & - & 6 \\
\hline filmovi & 1,5 & 3 & 4 & 0 & - & 3 \\
\hline peleti & 0 & 0 & 21 & 3 & - & 0 \\
\hline granule & 0 & 0 & 0 & 0 & - & 0 \\
\hline stiropor & 2,5 & 7 & 6 & 60 & - & 0 \\
\hline & & & & & & 100 \\
\hline broj čestica / kg sedimenta & 550 & 1500 & 850 & 4050 & 100 & 100 \\
\hline
\end{tabular}

analiziranim uzorcima, koji mogu biti dio proizvedene plastike ili adsorbirani iz vode na površinu plastike. ${ }^{41-43}$

\subsubsection{Južni Jadran}

Rezultati istraživanja koje je provedeno 2013. godine ukazuju kako se i u južnom Jadranu mogu pronaći visoke koncentracije mikroplastike. ${ }^{44}$ Za uzorkovanje mikroplastike upotrijebila se mreža veličine pora $200 \mathrm{~mm}$ tijekom razdoblja 5 - 6 min. $U$ tom razdoblju prikupljene su ukupno 5163 čestice, od kojih je većina bila nepravilnog oblika $(97,4 \%) .{ }^{44} U$ laboratoriju su čestice plastike ručno izdvojene pomoću stereo mikroskopa te se odredila veličina čestica. Od ukupnog broja čestica 53,8 \% čestica dimenzijama je bilo manje od 0,5 mm, a čak 29,4 \% čestica bilo je manje i od $0,3 \mathrm{~mm} \cdot{ }^{44}$ Analizom čestica identificirano je 16 različitih polimernih klasa od kojih je dominantan bio polietilen s udjelom od 41,2 \%.44 Dokazano je da se u južnom Jadranu nalaze velike količine različitih vrsta mikroplastike. $^{44}$

\section{Zaključak}

Onečišćenja plastikom kao i mikroplastikom predstavljaju problem na svjetskoj razini. Napretkom industrije i masovnijom uporabom plastike u svakodnevnom životu drastično se povećala količina mikroplastike koja završi u okolišu. Prisutnost mikroplastike u okolišu ima negativne posljedice za biljni i životinjski svijet. Jednom kad mikroplastika uđe u organizam, uzrokuje štetne učinke na fiziologiju, probavni, živčani, mišićni i spolni sustav pa čak i moguću smrt. Prijetnju okolišu ne stvara samo mikroplastika već i ksenobiotici koji se mogu adsorbirati na površinu mikroplastike i time uzrokovati štetnije učinke od same mikroplastike. Ispitivanja provedena na algama ukazuju na to da mikroplastika zaustavlja rast, smanjuje proizvodnju klorofila, onemogućava fotosintezu i dolazi do promjene u morfologiji stanica. Mikroplastika je detektirana i u Jadranskom moru te predstavlja ekološki problem. Prema količini i zastupljenosti plastičnog otpada, Jadransko more je najonečišćenije u Europi nakon sjeveroistočnog dijela Sredozemnog i Keltskog mora. Istraživanja su pokazala da su u sjevernom Jadranu (Tršćanski zaljev) detektirane izrazito visoke koncentracije mikroplastike, prosječne vrijednosti od oko 406000 čestica $/ \mathrm{km}^{2}$, što je do sad među najvišim zabilježenim koncentracijama u Mediteranskom moru. Shodno navedenom, nužna je zakonska regulativa o dopuštenim količinama mikroplastike koje se mogu naći kako u okolišu tako i u vodi za piće i vodenim organizmima namijenjenim za ljudsku prehranu.

\section{ZAHVALA}

Ovim putem zahvaljujemo Hrvatskoj zakladi za znanost, koja je u sklopu Primjena naprednih tehnologija obrade voda za uklanjanje mikroplastike IP-04-2019-9661 financirala znanstveno-istraživački rad.

\section{Popis kratica List of abbreviations}

\begin{tabular}{|c|c|}
\hline PP & $\begin{array}{l}\text { - polipropilen } \\
\text { - polypropylene }\end{array}$ \\
\hline PE & $\begin{array}{l}\text { - polietilen } \\
\text { - polyethylene }\end{array}$ \\
\hline PS & $\begin{array}{l}\text { - polistiren } \\
\text { - polystyrene }\end{array}$ \\
\hline PVC & $\begin{array}{l}\text { - poli(vinil-klorid) } \\
\text { - polyvinyl chloride }\end{array}$ \\
\hline PET & $\begin{array}{l}\text { - poli(etilen-tereftalat) } \\
\text { - polyethylene terephthalate }\end{array}$ \\
\hline PA & $\begin{array}{l}\text { - poliamid } \\
\text { - polyamide }\end{array}$ \\
\hline PBC & $\begin{array}{l}\text { - poliklorirani bifenil } \\
\text { - polychlorinated biphenyl }\end{array}$ \\
\hline $\mathrm{PAH}$ & $\begin{array}{l}\text { - policiklički aromatski ugljikovodik } \\
\text { - polycyclic aromatic hydrocarbons }\end{array}$ \\
\hline $\mathrm{HCH}$ & $\begin{array}{l}\text { - heksaklorcikloheksan } \\
\text { - hexachlorocyclohexane }\end{array}$ \\
\hline DDT & $\begin{array}{l}\text { - diklordifeniltrikloretan } \\
\text { - dichlorodiphenyltrichloroethan }\end{array}$ \\
\hline
\end{tabular}




$\begin{array}{ll}r & - \text { polumjer } \\ & - \text { radius } \\ \text { ROS } & - \text { reaktivne vrste kisika } \\ & - \text { reactive oxygen species } \\ \text { WWF } & - \text { Svjetski fond za prirodu } \\ & - \text { World Wide Fund for Nature } \\ \text { DeFishGear } & - \text { Sustav gospodarenja napuštenom ribolovnom } \\ & \text { opremom u Jadranskoj regiji } \\ & - \text { Derelict Fishing Gear Management System in the } \\ & \text { Adriatic Region } \\ \text { PES } & - \text { poliester } \\ & - \text { polyester } \\ \text { PAN } & - \text { poliakrilonitrin } \\ & - \text { polyacrylonitrile } \\ \text { PO } & - \text { poliolefin } \\ & - \text { polyolefin } \\ \text { PU } & - \text { poliuretan } \\ & - \text { polyurethane }\end{array}$

\section{Literatura}

\section{References}

1. C. G. Alimba, C. Faggi, Microplastics in the marine environment: current trends in environmental pollution and mechanisms of toxicological profile, Environ. Toxicol. Phar. 68 (2019) 61-74, doi: https://doi.org/10.1016/j. etap.2019.03.001

2. W. Wang, H. Gao, S. Jin, R. Li, G. Na, The ecotoxicological effects of microplastics on aquatic food web, from primary producer to human: A review, Ecotox. Environ. Safe 173 (2019) 110-117, doi: https://doi.org/10.1016/j. ecoenv.2019.01.113.

3. A. B. Silva, M. F. Costa, A. C. Duarte, Biotechnology advances for dealing with environmental pollution by micro(nano)plastics: Lessons on theory and practices, Curr. Opin. Environ. Sci. Health 1 (2018) 30-35, doi: https://doi.org/10.1016/j. coesh.2017.10.005.

4. X. Guo, J. Wang, The chemical behaviors of microplastics in marine environment: A review, Mar. Pollut. Bull. 142 (2019) 1-14, doi: https://doi.org/10.1016/j.marpolbul.2019.03.019.

5. J. Sun, X. Dai, Q. Wang, M. C. M. van Loosdrecht, B. J. Ni, Microplastics in wastewater treatment plants: Detection, occurrence and removal, Water Res. 152 (2019) 21-37, doi: https://doi.org/10.1016/j.watres.2018.12.050.

6. C. B. Crawford, B. Quinn, Microplastic Pollutants, The interactions of microplastics and chemical pollutants, Amsterdam, 2017., str. 131-157.

7. M. Barletta, A. R. A. Lima, M. F. Costa, Distribution, sources and consequences of nutrients, persistent organic pollutants, metals and microplastics in South American estuaries, Sci. Total. Environ. 651 (2019) 1199-1218, doi: https://doi. org/10.1016/j.scitotenv.2018.09.276.

8. A. P. Worth, Types of Toxicity and Applications of Toxicity Testing, u M. Balls, R. Combes, A. P. Worth, The History of Alternative Test Methods in Toxicology, London, 2019., str. 7-10.

9. M. D. Prokić, T. B. Radovanović, J. P. Gavrić, C. Faggio, Ecotoxicological effects of microplastics: examination of biomarkers, current state and future perspectives, TrAC Trend. Anal. Chem. 111 (2019) 37-46, doi: https://doi.org/10.1016/j. trac.2018.12.001.
10. V. Thiagarajan, V. P. A. J. Iswarya, R. Seenivasan, N. Chandrasekaran, A. Mukherjee, Influence of differently functionalized polystyrene microplastics on the toxic effects of P25

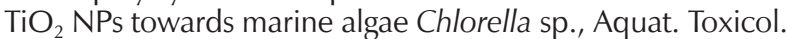
207 (2019) 208-216, doi: https://doi.org/10.1016/j.aquatox.2018.12.014.

11. S. M. Harmon, The Effects of Microplastic Pollution on Aquatic Organisms, Microplastic Contamination in Aquatic Environments, 2018., str. 249-270.

12. S. Garrido, M. Linares, J. A. Campillo, M. Albentosa, Effect of microplastics on the toxicity of chlorpyrifos to the microalgae Isochrysis galbana, clone t-ISO, Ecotox. Environ. Safe 173 (2019) 103-109, doi: https://doi.org/10.1016/j. ecoenv.2019.02.020.

13. C. Cunha, M. Faria, N. Nogueira, A. Ferreira, N. Cordeiro, Marine vs freshwater microalgae exopolymers as biosolutions to microplastics pollution, Environ. Pollu. 249 (2019) 372-380, doi: https://doi.org/10.1016/j.envpol.2019.03.046.

14. Z. Zhu, S. Wang, F. Zhao, S. Wang, F. Liu, G. Liu, Joint toxicity of microplastics with triclosan to marine microalgae Skeletonema costatum, Environ. Pollut. 246 (2019) 509-517, doi: https://doi.org/10.1016/j.envpol.2018.12.044.

15. Y. Wu, P. Guo, X. Zhang, Y. Zhang, S. Xie, J. Deng, Effect of microplastics exposure on the photosynthesis system of freshwater algae, J. Hazard. Mater. 374 (2019) 219-227, doi: https://doi.org/10.1016/j.jhazmat.2019.04.039.

16. S. L. Wright, F. L. Kelly, Plastic and human health: a micro issue?, Environ. Sci. Technol. 51 (2017) 6634-6647, doi: https://doi.org/10.1021/acs.est.7b00423.

17. I. L. Nerland, C. Halsband, I. Allan, K. V Thomas, Report made for the Norwegian Environment Agency, Microplastics in marine environments: Occurrence, distribution and effects, Norwegian Institute for Water Res., 2014., str. 1-71.

18. C. J. Moore, Synthetic polymers in the marine environment: A rapidly increasing, longterm threat, Environ. Res. 108 (2008) 131-139, doi: https://doi.org/10.1016/j.envres.2008.07.025

19. M. A. A. Browne, S. J. J. Niven, T. S. S. Galloway, S. J. J. Rowland, R. C. C. Thompson, Microplastic Moves Pollutants and Additives to Worms, Reducing Functions Linked to Health and Biodiversity, Curr. Biol. 23 (2013) 2388-2392, doi: https://doi.org/10.1016/j.cub.2013.10.012.

20. J. A. Ivar do Sul, M. F. Costa, The present and future of microplastic pollution in the marine environment, Environ. Poll. 185 (2014) 352-364, doi: https://doi.org/10.1016/j. envpol.2013.10.036.

21. A. E. Ganning, U. Brunk, G. Dallner, Phthalate esters and their effect on the liver, Hepatology 4, 1984., str. 541-547.

22. I. Čatić, M. Šercer, Proizvodnja polimernih tvorevina, Društvo za plastiku i gumu, Zagreb, 2004.

23. URL: http://mediterranean.panda.org/ news/?uNewsID=301993 (5. 5. 2019.).

24. F. Wang, C. S. Wong, D. Chen, X. Lu, F. Wang, E. Y. Zeng, Interaction of toxic chemicals with microplastics: A critical review, Water Res. 139 (2018) 208-219, doi: https://doi. org/10.1016/j.watres.2018.04.003.

25. A. L. Andrady, Microplastic in the marine environment, Mar. Pollut. Bull. 62 (2011) 1596-1605, doi: https://doi. org/10.1016/j.marpolbul.2011.05.030.

26. A. Colligon, J. H. Hecq, F. Galgani, F. Collard, A. Goffart, Annual variation i neurostonic micro- and meso-plastic particles and zooplankton in the Bay of Calvi (Mediterranean-Corsica), Mar. Pollut. Bull. 79 (2014) 293-298, doi: https://doi. org/10.1016/j.marpolbul.2013.11.023.

27. Y. Ogata, H. Takada, K. Mizukawa, H. Hirai, S. Iwasa, S. Endo, 
Y. Mato, M. Saha, K. Okuda, A. Nakashima, M. Murakami, N. Zurcher, R. Booyatumanondo, M. P. Zakaria, Dung le Q, M. Gordon, C. Miguez, S. Suzuki, C. Moore, H. K. Karapanagioti, S. Weerts, T. McClurg, E. Burres, W. Smith, M. Van Velkenburg, J. S. Lang, R. C. Lang, D. Laursen, B. Danner, N. Stewardson, R. C. Thompson, International Pellet Watch: global monitoring of persistent organic pollutants (POPs) in coastal waters. 1. Initial phase data on PCBs, DDTs, and HCHs. Mar. Pollut. Bull. 58 (2009) 1437-1446, doi: https:// doi.org/10.1016/j.marpolbul.2009.06.014.

28. J. Wang, Z. Tan, J. Peng, Q. Qiu, M. Li, The behaviors of microplastics in the marine environment, Mar. Environ. Res. 113 (2016) 7-17, doi: https://doi.org/10.1016/j.marenvres.2015.10.014.

29. P. Tutman, D. Bojanić-Varezić, M. Prvan, J. Božanić, M. Nazlić, J. Šiljić, M. Pavičić, Integrirano planiranje u cilju smanjivanja utjecaja morskog otpada, projekt DeFishGear, Tehnoeko, 2017., str. 2-11.

30. F. Galgani J. P. Leaute, P. Moguedet, A. Souplet, Y. Verin, A. Carpentier, H. Goraguerà, D. Latrouite, B. Andral, Y. Cadiou, J. C. Mahe, J. C. Poulard, P. Nerisson, Litter on the sea floor along European coasts, Mar. Pollut. Bull. 40 (2000) 516-527, doi: https://doi.org/10.1016/S0025-326X(99)00234-9.

31. R. Marchetti, A. Provini, G. Crosa, Nutrient load carried by the River Po into the Adriatic Sea, 1968-1987, Mar. Pollut. Bull. 20 (1989) 168-172, doi: https://doi.org/10.1016/0025326X(89)90487-6.

32. Ž. Kwokal, B. Štefanović, Plutajući otpad iz mora zanemarivanje ne znači nepostojanje, Adriatic Boat Show 2009, Šibenik, Hrvatska, 2009., str. 17-21.

33. T. Vlachogianni, T. Fortibuoni, F. Ronchi, C. Zeri, C. Mazziotti, P. Tutman, D. Bojanić Varezić, A. Palatinus, Ś. Trdan, M. Peterlin, M. Mandić, O. Markovic, M. Prvan, H. Kaberi, M. Prevenios, J. Kolitari, G. Kroqi, M. Fusco, M. Scoullos, Marine litter on the beaches of the Adriatic and Ionian Seas: An assessment of their abundance, composition and sources, Mar. Pollut. Bull. 20 (2018) 745-756, doi: https://doi. org/10.1016/j.marpolbul.2018.05.006.

34. T. Gajšt, Sea surface microplastics in Slovenian part of the Northern Adriatic, Mar. Pollut. Bul. 113 (2016) 1-8, doi: https://doi.org/10.1016/j.marpolbul.2016.10.031.
35. B. K. L. Laglbauer, Macrodebris and microplastics from beaches in Slovenia, Mar. Pollut. Bull. 89 (2014) 1-11, doi: https://doi.org/10.1016/j.marpolbul.2014.09.036.

36. C. J. Moore, Synthetic polymers in the marine environment: a rapidly increasing, long-term threat, Environ. Res. 108 (2008) 131-139, doi: https://doi.org/10.1016/j.envres.2008.07.025

37. P. Farrell, K. Nelson, Trophic level transfer of microplastic: Mytilus edulis (L.) to Carcinus maenas (L.), Environ. Pollut. 177 (2013) 1-3, doi: https://doi.org/10.1016/j.envpol.2013.01.046.

38. M. C. Fossi, C. Panti, C. Guerranti, D. Coppola, M. Giannetti, L. Marsili, R. Minutoli, Are baleen whales exposed to the threat of microplastics? A case study of the Mediterranean fin whale (Balaenoptera physalus), Mar. Pollut. Bull. 64 (2012) 2374-2379, doi: https://doi.org/10.1016/j.marpolbul.2012.08.013

39. G. Pellini, Characterization of microplastic litter in the gastrointestinal tract of Solea solea from the Adriatic Sea, Environ. Pollut. 234 (2018) 943-952, doi: https://doi.org/10.1016/j. envpol.2017.12.038.

40. A. Palatinus, G. Suaria, M. Viršek, J. Šiljić, O. Bajt, M. Grego, $U$. Robič, Marine litter in the Croatian part of the middle Adriatic Sea: Simultaneous assessment of floating and seabed macro and micro litter abundance and composition, Mar. Pollut. Bull. 139 (2019) 427-439, doi: https://doi. org/10.1016/j.marpolbul.2018.12.038.

41. J. Maršić-Lučić, J Lušić, P. Tutman, D. Bojanić Varezić, J. Šiljić, J. Pribudić, Levels of trace metals on microplastic particles in beach sediments of the island of Vis, Adriatic Sea, Croatia, Mar. Pollut. Bull. 137 (2018) 231-236, doi: https://doi. org/10.1016/j.marpolbul.2018.10.027.

42. URL: https://journals.plos.org/plosone/article?id=10.1371/ journal.pone.0191759 (4. 4. 2019.).

43. M. Rochman, B. T. Hentschel, S. J. Teh, Long-term sorption of metals is similar among plastic types: implications for plastic debris in aquatic environments, Plos One 9 (2014) 1-10, doi: https://doi.org/10.1371/journal.pone.0085433.

44. G. Suaria, C. G. Avio, G. Lattin, F. Regoli, S. Aliani, Fate and Impact of Microplastics in Marine Ecosystems, Floating Microplastics in the South Adriatic Sea, 2017., str. 51-52.

\title{
SUMMARY \\ Microplastics in the Marine Environment of the Adriatic Sea \\ Kristina Bule, ${ }^{a}$ Karla Zadro, ${ }^{a}$ Ana Tolić, ${ }^{a}$ Edi Radin, ${ }^{a}$ Martina Miloloža, Vesna Ocelić Bulatović, and Dajana Kučić Grgića*
}

The widespread use of plastics has led to the accumulation of plastics in all parts of the environment where it adversely affects the ecosystem. Plastic pollution has the biggest impact on the marine ecosystems which assimilate about 12.7 million tons of plastic yearly. Because of incomplete degradation, plastic in marine environment is accumulated in the form of large clusters and microplastic. Microplastic has a harmful impact on marine organisms due to the accumulation of toxic compounds adsorbed on its particles, which could be passed through the food chain and eventually to humans. Certain researches discussed in this paper are focused on the characterization and quantification of microplastic found in the Adriatic Sea.

\author{
Keywords \\ a University of Zagreb, Faculty of Chemical \\ Engineering and Technology, Marulićev trg 19, \\ 10000 Zagreb, Croatia \\ ${ }^{\mathrm{b}}$ University of Zagreb, Faculty of Metallurgy, \\ Aleja narodnih heroja 3, 44000 Sisak, Croatia
}

Microplastic, plastic pollution, marine environment, toxicity, Adriatic Sea 